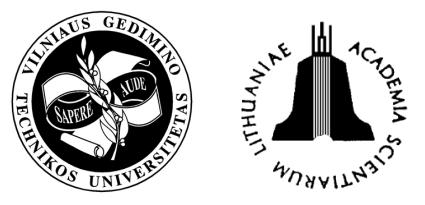

\title{
RESEARCH ON THE STRUCTURE OF CARGO FLOW IN LATVIA
}

\author{
Elina Meirane \\ Transport and Telecommunication Institute, Lomonosova 1, LV-1019 Riga, Latvia \\ Tel.: +371 2967744, e-mail: elinee@inbox.lv
}

Received 14 January 2007; accepted 2 May 2007

\begin{abstract}
The article provides analysis of the transport branch in Latvia in the period of time from 1999 to 2005 . The notion of multimodality and its role in the development of logistics are viewed. By analyzing statistical data about the distribution of the cargo flow by each kind of transport, the author of the article has examined the existence of multimodality for creation of the logistics centers in Latvia.

Furthermore, there is analysis of the cargo flow in the regions of Latvia and its distribution among the types of transport and kinds of communications in order to determine the territories prior to creation of a specific kind of a logistics center.
\end{abstract}

Keywords: cargo flow, logistics center, multimodality, statistical data, modes of transport, types of transportation, regions of Latvia.

\section{Introduction}

In Latvia as well as in other countries the growth of economy depends on the development of the transport branch and the infrastructure of logistics related to it. In the USA and Europe the expenditure on logistics comprises $8.6 \%$ and $7.8 \%$ of GDP, respectively. The volume of the world market of transport-logistics services is estimated of $\$ 1500$ billion, which is about $4.7 \%$ of the global GDP.

The proportion of revenue from the transport branch in GDP of Latvia has been on average $13.5 \%$ since 1999, it is 2.87 times higher than the respective global indicator. Thus, it can be concluded that in Latvia transport is one of the branches forming the state revenue.

Regardless the continuous growth of GDP from 1999 to 2005 (the increase is $136 \%$ ), the proportion of the revenue from the transport branch in this period of time has increased only by $0.38 \%$ (Fig 1 ). Insubstantial improvement of the economic indicators in the transport branch is observed due to the ineffective use of its potential both locally and globally. It can be proved by:

- the lack of a conception for technological development;

- the lack of interrelation between participants of transport carrying the cargoes of material, financial, information, etc. flow (functional peculiarity of Logistics center);

- the irrational use of transit opportunities (decreasing flow of cargo in Ventspils Port, Estonian transit etc.).
The data of the macroeconomic overview made by SEB UNIBANKA for the period of 9 months of the year 2006 show that the problems of transit in Latvia are still unsolved:

- during 9 months of the year 2006 the total volume of transit cargoes decreased by $10 \%$;

- in same period of time the turnover in ports increased only by $1 \%$ and reached 45.3 million tons. The turnover of Ventspils Port was 22 million tons ( $-1 \%)$, Riga Port 19.5 million tons $(+7 \%)$, Liepaja Port 3 million tons $(-3 \%)$;

- railroad transit cargoes decreased by $8.5 \%$ and were 37.3 million tons. It is the lowest level during the last 3 years [1].

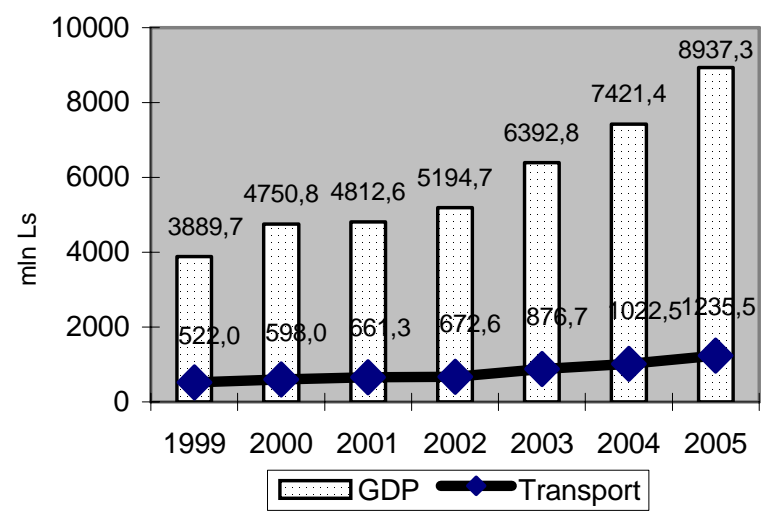

Fig 1. The proportion of transport revenue in GDP in Latvia from 1998 to 2005 
One of the solutions to all of these problems mentioned above could be creation of Logistics Center (LC). In the article [2] there are several models of logistics centers in European countries described, and characteristics of the structure and choice of an optimal model of a logistics center are determined.

Creation of competitive logistics in Latvia, organization of a logistics center can be carried out in case a full spectrum of transport services, e. g., multimodality is provided. The article investigates the opportunities for carrying out this condition in Latvia on the whole and in separate regions in order to find out the most advantageous territory for creation of a logistics center.

\section{The notion of multimodality}

Currently in European transport logistics there is no single conception and typology in transport logistics for creation of multimodal logistics centers. It is developing all the time having various models and projects of development. During the last 5 years in the framework of several European projects there have been considered various conceptions and notions of logistics centers, multimodality as well as there have been worked out approaches to the transfer of experience to the new Member States of the EU. The notion and samples of creating multimodal logistics centers in several European countries are reviewed in [2].

There can be two notions mentioned:

- multimodality - it is sequential transportation of cargoes by two or more modes of transport [3];

- multimodal - linkage of different transport modes for quick transshipment [4].

Basing on these notions it can be concluded that the priority of this transportation is making transportation of cargoes cheaper by using modes of transport having low costs and low transport tariffs. Road transport is an expensive mode of transport used for bringing cargoes to the railroads and ports. The rest of the long transportation distance of cargo delivery can be managed by railroad and maritime transport [3].

\section{Analysis of the structure of cargo flow in Latvia from 1999 to 2005}

In Latvia transportation of cargoes is carried out by using four modes of transport: maritime, railroad, road and air transport. In Fig 2 there is statistical data about transportation of cargoes using various modes of transport in Latvia.

In the respective period of time the total volume of cargo transportation on average has increased 2 times: by air transport -3.64 times, railroad transport -1.81 times, road transport -1.54 times, maritime transport 1.22 times. Regardless of rather substantial increase in the cargo flow by air transport in this period, the main modes of transport in delivery of cargoes still are maritime transport and railroad transport (see Fig 3) having approximately similar volumes of cargoes in 2005, respectively 60042 thsd of tons and 60068 thsd of tons.

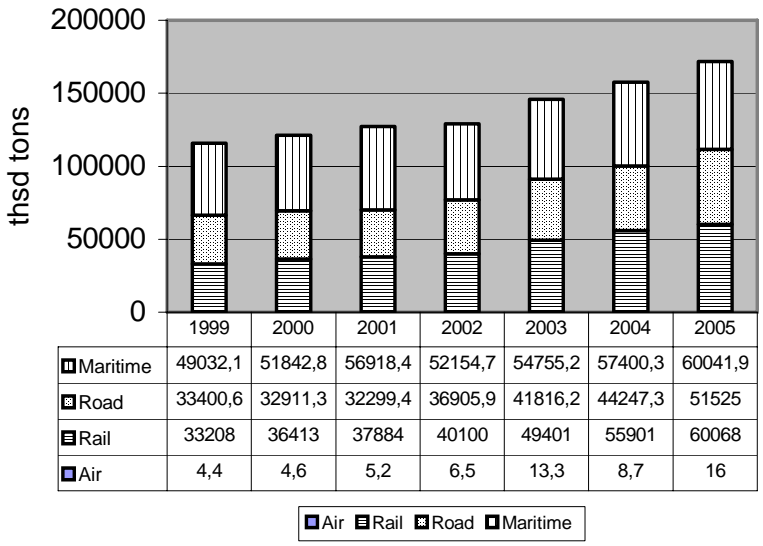

Fig 2. Distribution of the volume of cargoes by modes of transport in Latvia in the period of time from 1999 to 2005 (thsd tons)

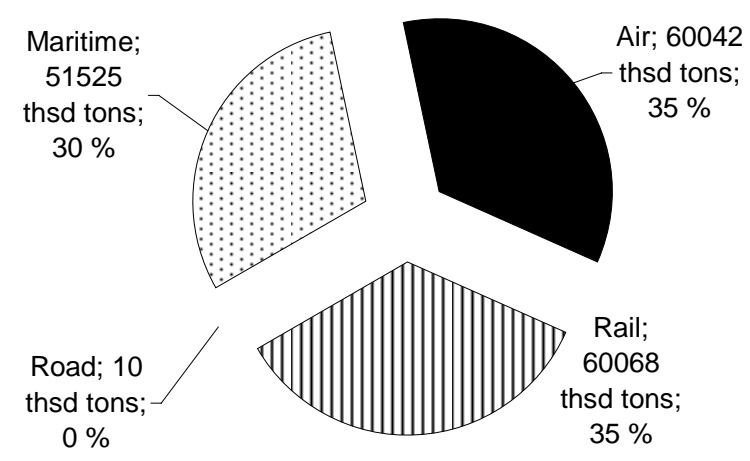

Fig 3. Distribution of the volume of cargoes by modes of transport in Latvia in 2005

By types of communications the cargoes to be delivered can be divided into internal and external. The internal ones are cargoes to be delivered within the country, but the external ones are cargoes to be divided into 3 categories: import, export and transit. Fig 4 and Table 1 provide data about distribution of the cargo flow by types of communications and modes of transport in the period of time from 1999 to 2005 [5-7].

During the last six years in maritime transport export cargoes were prevailing, in road transport - internal cargoes, in railroad transport - transit cargoes till 2002, increasing import cargoes since 2003.

In the period of time from 1999 to 2005 the proportion of export cargoes has increased by $25 \%$, import cargoes - by $528 \%$, internal cargoes - by $62 \%$, but the proportion of transit cargoes has decreased by $289 \%$.

Losing transit cargoes and keeping constant export and internal cargoes, Latvia has managed to improve slightly the indicators of the cargo turnover in the period of time from 1999 to 2005 by increasing substantially the volume of import cargoes. 


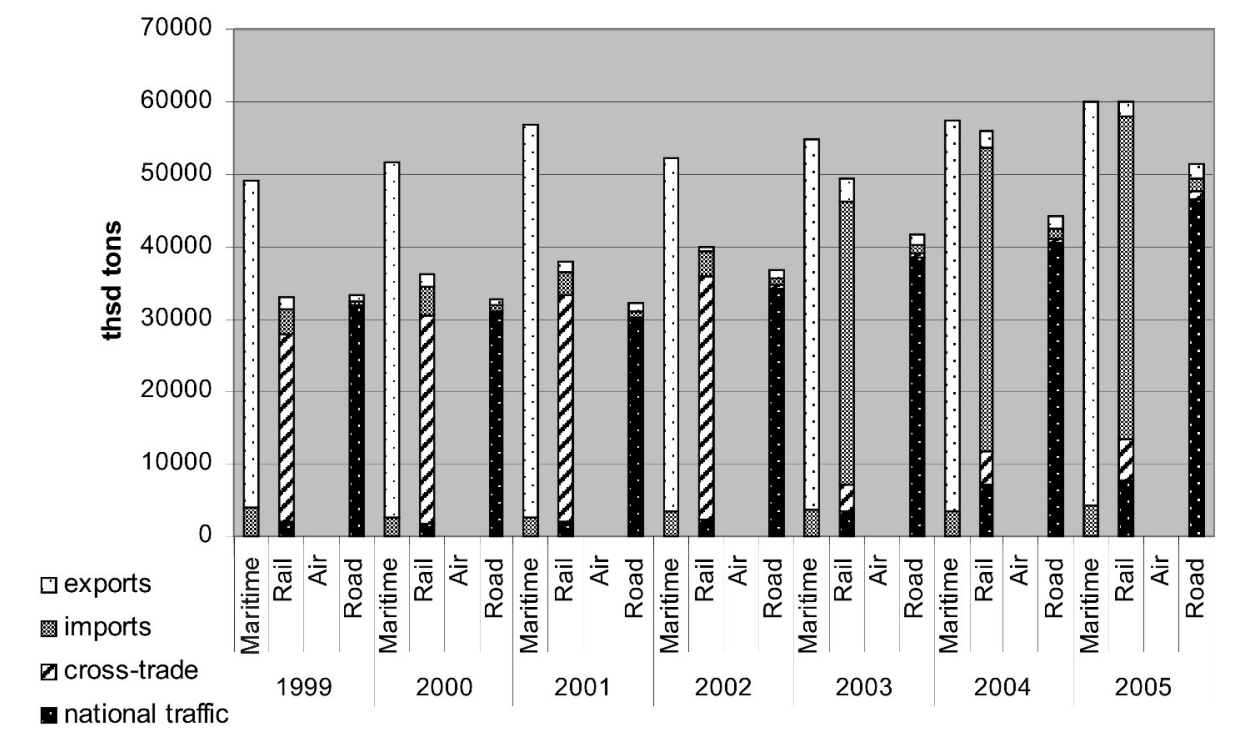

Fig 4. Components of the cargo flow by modes of transport in Latvia from 1999 to 2005

Table 1. Statistical data about transportation of cargoes by types of communications and modes of transport in Latvia from 1999 to 2005

\begin{tabular}{|c|l|c|c|c|c|}
\hline \multirow{4}{*}{ Year } & Transport & $\begin{array}{c}\text { Tational } \\
\text { traffic }\end{array}$ & $\begin{array}{c}\text { Tross- } \\
\text { trade }\end{array}$ & imports & exports \\
\hline \multirow{5}{*}{1999} & Maritime & 0 & 0 & 3886,7 & 45145,4 \\
\cline { 2 - 6 } & Rail & 1938 & 26030 & 3577 & 1663 \\
\cline { 2 - 6 } & Air & 0 & 0 & 3,4 & 1 \\
\cline { 2 - 6 } & Road & 31718,1 & 262 & 560,9 & 859,6 \\
\hline \multirow{5}{*}{2000} & Maritime & 0 & 0 & 2567,3 & 49275,5 \\
\cline { 2 - 6 } & Rail & 1753 & 28724 & 4000 & 1936 \\
\cline { 2 - 6 } & Air & 0 & 0 & 3,5 & 1,1 \\
\cline { 2 - 6 } & Road & 30926,2 & 349 & 642,8 & 993,3 \\
\hline \multirow{4}{*}{2001} & Maritime & 0 & 0 & 2546,1 & 54372,3 \\
\cline { 2 - 6 } & Rail & 2011 & 31278 & 3373 & 1222 \\
\cline { 2 - 6 } & Air & 0 & 0 & 4 & 1,2 \\
\cline { 2 - 6 } & Road & 29991,8 & 370,4 & 913,7 & 1023,5 \\
\hline \multirow{5}{*}{2002} & Maritime & 0 & 0 & 3419,5 & 48735,2 \\
\cline { 2 - 6 } & Rail & 2314 & 33632 & 3442 & 662 \\
\cline { 2 - 6 } & Air & 0 & 0 & 5,1 & 1,4 \\
\cline { 2 - 6 } & Road & 34297,4 & 497 & 918,4 & 1193,1 \\
\hline \multirow{5}{*}{2003} & Maritime & 0 & 0 & 3836,9 & 50918,3 \\
\cline { 2 - 6 } & Rail & 3375 & 3683 & 39359 & 2984 \\
\cline { 2 - 6 } & Air & 0 & 0 & 12 & 1,3 \\
\cline { 2 - 6 } & Road & 38665,3 & 490 & 1172,1 & 1488,8 \\
\hline & Maritime & 0 & 0 & 3299,5 & 54100,8 \\
\cline { 2 - 6 } & Rail & 7271 & 4568 & 41895 & 2167 \\
\cline { 2 - 6 } & Air & 0 & 0 & 7,2 & 1,5 \\
\hline & Road & 40656,4 & 561,1 & 1285,8 & 1744 \\
\hline & Raril & 7840 & 5704 & 44532 & 1992 \\
\hline & 46633 & 1060,2 & 1760 & 2071,8 \\
\hline
\end{tabular}

\section{Analysis of the Structure of Cargo Flow in the Regions of Latvia in 2005}

In this part of the article distribution of the cargo flow by modes of transport is analyzed in the regions of Latvia - Riga, Riga district, Vidzeme, Kurzeme, Zemgale and Latgale in 2005. There can be mentioned several basic tendencies and peculiarities of the cargo flow in regions (see Fig 5).

The central region, Riga, is the leading one if taking into consideration the number of the used modes of transport - there all 4 modes are used. The proportion of the delivered cargoes of this region comprises one fifth $(20.1 \%)$ out of the total volume of all six regions.

Kurzeme, of course, is the leading region if taking into consideration the total volume of cargoes $(33.2 \%)$, besides, just as in Riga district (11.9\%) there 3 modes of transport (road, railroad and maritime) are used when delivering cargoes.

Two modes of transport (road and railroad) are used in such regions as Zemgale (11\% out of the total turnover of cargoes), Vidzeme (12.7\%) and Latgale $(11.1 \%)$. It is determined by their geographical location.

The following relations can be observed if taking into consideration the ratio of each mode of transport for delivery of cargoes in each region to the total volume of cargoes delivered by each mode of transport (see Fig 6).

\section{Conclusions}

As currently there is no clear conception regarding development of transport logistics in Latvia, the following problems are observed: loss of the cargo flow volume, increase of delivery costs, lack of coordination in usage of modes of transport, etc. One of the possible solutions is creation of a logistics center. 


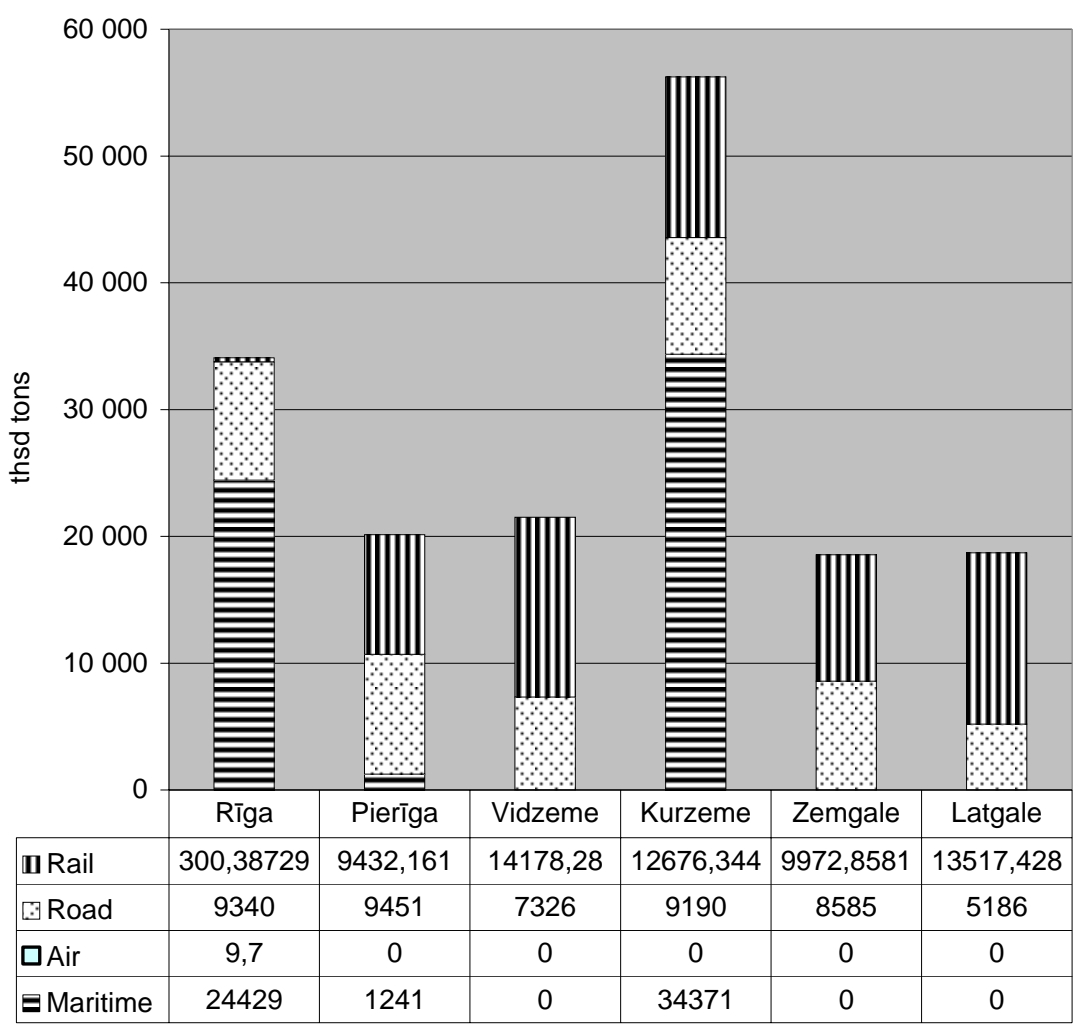

Fig 5. Distribution of cargo flow by modes of transport in the regions of Latvia in 2005

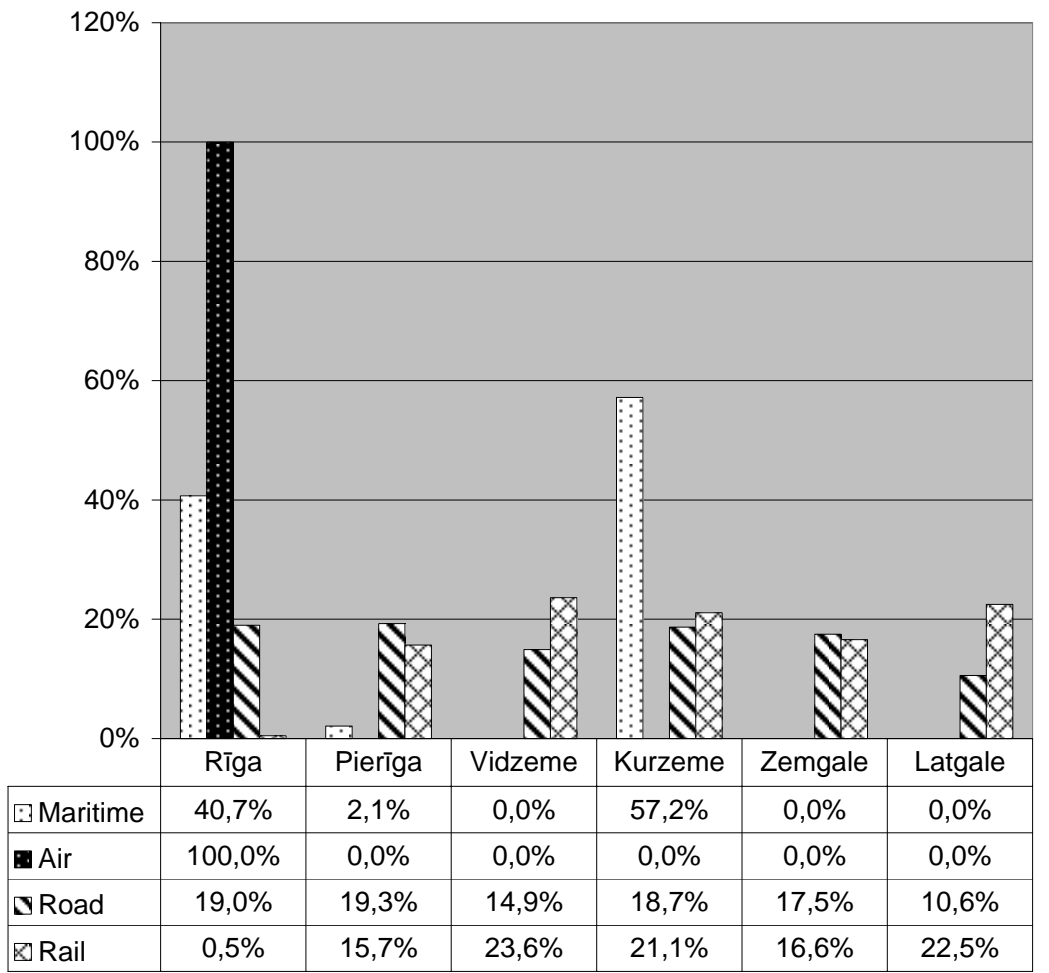

Fig 6. Distribution of cargo flow in percentage out of the total volume by modes of transport in the regions of Latvia in 2005 
Taking into consideration the peculiarities of the transport branch in Latvia and the tendencies of its development to attract the cargo flow to the European and Eastern directions, it is necessary to solve the following burning problems:

- to work out a conception of attracting cargo flow;

- to assess the opportunities for acceptance and transportation of cargoes.

Basing on the analysis of the cargo flow in Latvia, some features of multimodality are traced. Taking into account the prevalence of railroad and maritime transport in the transport branch as well as the current situation in the distribution of the cargo flow, the most appropriate location for multimodal centers of various levels could be Riga district and Kurzeme.

\section{References}

1. Website of SEB Unibanka. Available from Internet: <www.seb.lv/lv/about/press-centre>.

2. MEIRANE, E. The comparative analysis of creation of the models for transport-logistics centers in Europe (Сравнительный анализ моделей создания транспортно-логистических центров в Европе). In The 6th International Conference "Reliability and Statistics in Transportation and Communication - 2006 (RelStat'06)”, Riga, Latvia, 25-28 October 2006. Riga: TSI, p. 278-284 (in Russian).

3. KURGANOV, V. M. Logistics. Transport and a warehouse in the chain of the goods deliveries (Логистика. Транспорт и склад в цепи поставок товаров). Moscow: Knizhnij mir, 2005. 432 p. (in Russian).

4. Networking logistics centers in the Baltic Region (NeLoc). Best Practice Handbook for Logistics Centers in the Baltic Sea Region, 2003.

5. Website of Road Transport Administration. Available from Internet: 〈http://www.atd.lv/lat/statistika>.

6. Latvijas Republikas Centrālā statistikas Pārvalde. Transports 2005.gadā. Statistisko datu krājums. Rīga, 2006 Available from Internet: 〈www.csb.gov.lv>.

7. Latvijas Republikas Centrālā statistikas Pārvalde. Transports 2002.gadā. Statistisko datu krājums. Rīga, 2003 Available from Internet: <www.csb.gov.lv>. 